DOI: https://doi.org/10.32836/2521-666X/2021-73-10

УДК 336.008 .8

\author{
Васютинська Л.А. \\ кандидат економічних наук, доцент, \\ доцент кафедри проєктного менеджменту, \\ Одеський регіональний інститут державного управління \\ Національної академії державного управління \\ при Президентові України
}

\title{
Vasyutynska Lyudmila
}

Odessa Regional Institute of Public Administration

NAPA under the President of Ukraine

\section{ФІНАНСУВАННЯ ІНФРАСТРУКТУРНИХ ПРОЕКТІВ НА ЗАСАДАХ ПУБЛІЧНО-ПРИВАТНОГО ПАРТНЕРСТВА: ФОРМИ ТА ІНСТРУМЕНТИ}

\author{
FINANCING OF PUBLIC INFRASTRUCTURE PROJECTS \\ ON THE BASIS OF PUBLIC-PRIVATE PARTNERSHIP: FORMS AND TOOLS
}

\begin{abstract}
У статті обтрунтовано суть проєктного фінансування інфраструктури на засадах публічно-приватного партнерства та досліджено форми і інструменти, які використовується у ході фінансової взаємодії публічного і приватного партнерів. Пояснено розуміння публічного інфраструктурного проєкту через розмежування його за иільовим спрямуванням та відповідно до зміни існуючого об'єкта нерухомості. Розкрито особливості реалізації публічних інфраструктурних проєктів. Досліджено основні засоби державної підтримки щодо фінансування проєктів публічно-приватного партнерства. 3 огляду на існуючу практику обтрунтовано інструменти інвестування інфраструктурних проєктів для публічного інвестора та приватного партнера. Розглянуто практику фінансування ТIF-проєктів та визначено можливості їх застосування в Україні.

Ключові слова: публічно-приватне партнерство, інфраструктурний проєкт, фінансові інструменти, публічний партнер, приватний партнер.
\end{abstract}

В статье обоснована суть проектного финансирования инфраструктуры на основе государственно-частного партнерства, а также исследованы формы и инструменты, которые используется в ходе финансового взаимодействия публичного и частного партнеров. Объяснено понимание публичного инфраструктурного проекта посредством разграничения его по иелевому направлению и в соответствии с изменением существующего объекта недвижимости. Раскрыты особенности реализации публичных инфраструктурных проектов. Исследованы основные средства государственной поддержки по финансированию проектов государственно-частного партнерства. Учитывая существующую практику, обоснованы инструменты инвестирования инфраструктурных проектов для публичного инвестора и частного партнера. Рассмотрена практика финансирования TIF-проектов и определены возможности их применения в Украине.

Ключевые слова: государственно-частное партнерство, инфраструктурный проект, финансовые инструменты, публичный партнер, частный партнер.

The significance of public-private partnership for the development of the socio-economic system of the state is extremely high, as public-private partnership can and should be positioned as one of the financial mechanisms capable of providing not only extensive but also intensive economic growth of territories and regions mainly for by financing the development of transport, social, service infrastructure and utilities, as well as to promote accelerated modernization in high-tech sectors of the national economy. In the article, the essence of project financing of infrastructure based on public-private partnership is substantiated, as well as the forms and tools that are used in the course of financial interaction between public and private partners are investigated. The essence of project financing of infrastructure based on public-private partnership is substantiated, the forms and tools that are used in the course of financial interaction between public and private partners as well are investigated. The understanding of a public infrastructure project is explained through differentiating it according to the goal direction and in accordance with the change of the existing real estate object. The main means of state support for financing public-private partnership projects is investigated. Taking into account the existing practice, it is reasonable to invest in infrastructure projects for a public investor and a private partner. The increased risks of the private partner are due to the fact that public-private partnership projects provide a higher cost of the project compared to budget funding. In addition, it is worth noting the potential cost of the project after to contract, taking into account the variability of the external environment. The practices of implementing TIF-projects are investigated and the essence of the financing instruments used for this are disclosed. The peculiarity of the application of TIF-projects is that these are used by local governments for the development of local territories or individual districts. These investigations provide opportunity to determine the conditions for the application of financing the increase in the tax rate in Ukraine.

Key words: public-private partnership, infrastructure project, financial instruments, public partner, private partner.

Постановка проблеми. Значимість публічно-приватного партнерства (ППП) для розвитку соціальноекономічної системи держави є вкрай великою, оскіль- ки ППП може і повинно позиціонуватися як один із фінансових механізмів, здатних забезпечити не тільки екстенсивне, а й інтенсивне економічне зростання те- 
риторій та регіонів, головним чином, за рахунок фінансування розвитку транспортної, соціальної, сервісної інфраструктури та комунальних послуг, а також сприяти прискореній модернізації у високотехнологічних галузях національної економіки. Водночас поява нових форм взаємовідносин між економічними агентами, постійне ускладнення соціально-економічної життя у цілому, потреба модернізації діючої інфраструктури на тлі обмеженості бюджету не дають змоги повною мірою виконувати державою свої функції, тому виникає потреба у залученні приватного капіталу. Водночас поступальний розвиток ринкових відносин змушує бізнес шукати нові об'єкти для інвестування з метою збільшення прибутків. Вигоди, які можуть виявитися від взаємодії цих зацікавлених сторін у ході вирішення соціально-економічних проблем, забезпечують синергетичний ефект для суспільства. Необхідність формування ефективних механізмів фінансування, які базуються на балансі інтересів і принципах максимізації взаємних вигід, визначає актуальність тематики дослідження.

Аналіз останніх досліджень і публікацій. Проблематикою організації і функціонування публічно-приватного партнерства переймаються дослідники різних сфер наукових інтересів, зокрема В. Геєць, А. Дедяло, М. Дерябіна, М. Клинова, С. Перегудов, С. Черевіков.

Здобутки науковців у рамках дослідженої тематики є досить значними, особливо у питаннях розкриття суті державно-приватного партнерства, визначення його переваг, форм реалізації і регулювання, з'ясування форм і методів взаємодії держави та бізнесу, оцінки поточного стану розвитку ППП в Україні, дослідження зарубіжного досвіду та ін.

Попри значну кількість напрацювань у цій сфері, низку актуальних завдань у ракурсі окресленої проблематики не розв'язано. Зокрема, потребують вивчення особливості проєктного фінансування ППП з огляду на розкриття суті інфраструктурного проєкту та його фінансового забезпечення.

Мета статті полягає в обгрунтуванні суті проєктного фінансування інфраструктури на засадах ППП і дослідженні форм та інструментів, які використовується у ході фінансової взаємодії публічного та приватного партнерів.

Виклад основного матеріалу. Як зазначається в літературних джерелах, вкладення капіталів в інфраструктурні проєкти не набуло активності серед інституціональних вкладників і приватних економічних агентів, хоча потреба в такій інвестиційній діяльності з огляду на період життєвого циклу інфраструктурних активів існує.

За оцінками Світового банку, десятивідсоткове зростання інфраструктурних активів безпосередньо веде до збільшення ВВП від 1\% до 10\% [1], а отже, недостатня або слаборозвинена інфраструктура являє собою одну з найбільших перешкод для соціально-економічного розвитку держави.

Партнерство держави 3 приватними економічними агентами передбачає узгодженість їхніх цілей щодо одержання вигід від цієї взаємодії. При цьому ефективність узгодженості залежить від достатньої і надійної передачі ризиків приватному партнеру. Окрім того, уряд визначає якість і кількість послуг, необхідних від приватного партнера, якому можуть бути доручені проєктування, будівництво, фінансування, експлуатація, управління інфраструктурними активами, а також надання послуг державі або населенню, що використовує цей інфраструктурний актив.

Для з'ясування предмету проєктного фінансування $\epsilon$ сенс поглибити розуміння публічного інфраструктурного проєкту через розмежування їх за цільовим спрямуванням:

- проєкти, що спрямовані на забезпечення транспортної інфраструктури, наприклад тунелі, мости, порти, дороги, залізничні системи і мережева інфраструктура;

- проєкти з надання комунальних послуг, наприклад виробництво електроенергії, видалення відходів, централізоване теплопостачання, водопостачання i телекомунікації;

- соціальні проєкти, об'єктом яких є соціальна та сервісна інфраструктура, яку, своєю чергою, можна розділити на стандартні активи, наприклад адміністративні будівлі, і активи за індивідуальним замовленням, наприклад школи, університети, лікарні та великі культурні установи.

Ще одна особливість проєктного фінансування інфраструктури полягає у розмежуванні проєктів відповідно до зміни існуючого об'єкта нерухомості. Йдеться про greenfield-проєкти та brownfield-проєкти. Перші являють собою девелопмент індустріальних територій (освоєння нових, незабудованих територій), тобто девелопер не обмежений у можливостях використання території з огляду на існування старих активів. Інші це проєкти, які мають за мету створення нового активу на основу існуючої інфраструктури, тобто являють собою редевелопмент індустріальних територій, екобаланс яких порушений у результаті господарської діяльності. Переваги перших і других досить розмиті, хоча на перший погляд brownfield- проєкти є більш капіталомісткими, ніж greenfield-проєкти, але не слід відкидати переваги brownfield-проєктів з огляду на існуючі комунікаційні мережі, які можуть біти використані під час реалізації такого проєкту.

В останні десятиліття модель публічно-приватного партнерства використовувалася урядами в усьому світі як засіб для інвестування в публічну інфраструктуру. Причини застосування ППП у цьому сенсі не потребують доказів, адже держава знижує свої ризики за рахунок приватного партнера i, крім цього, капітальні витрати також знижуються у рамках життєвого циклу активу. Проте приватний партнер, беручи на себе додаткові ризики, хоче отримати певні вигоди й одержати дохід. Саме такий контекст закладається в угоду між державою та приватним партнером. Однак ці переваги мають свою ціну. Підвищені ризики приватного партнера зумовлені тим, що проєкти ППП передбача- 
ють більш високу вартість проєкту порівняно з бюджетним фінансуванням. Окрім цього, варто звернути увагу на потенційне подорожчання проєкту після укладення контракту 3 огляду на мінливість зовнішнього середовища.

Обгрунтування моделі ППП для фінансування інфраструктури відрізняється від країни до країни. Для деяких країн ППП - спосіб оптимального перерозподілу бюджетних коштів у зв'язку з неможливістю здійснювати бюджетне інвестування, оскільки фонди капітальних видатків у структурі бюджету є досить обмеженими. Для інших причина полягала в тому, щоб отримати максимальне співвідношення ціни й якості.

Реалізація публічних інфраструктурних проєктів має свої особливості, які полягають у тому, що держава $\epsilon$ найбільш зацікавленою стороною в реалізації такого проєкту, оскільки у результаті отримуються суспільні блага. Загальна мета державного суб'єкта щодо продукту проєкту полягає у створенні найбільш можливої цінності від вкладених коштів. При укладанні договору між державним представником і приватним партнером оцінюються ризики проєкту і визначається та їх частина, яка може бути передана кожному з партнерів.

Проєктне фінансування може використовуватися в усіх моделях ППП, оскільки будь-який проєкт має бути забезпечений ресурсами, у тому числі й фінансовими коштами, а отже, через фінансовий механізм здійснюється залучення інвестицій і управління ними впродовж життєвого циклу проєкту.

Якщо досліджувати потенційні інструменти фінансування публічних інфраструктурних проєктів, то традиційна класифікація фінансових інструментів передбачається положеннями Міжнародного стандарту фінансової звітності, але в українських реаліях такий інструментарій не застосовується в повному обсязі. Державна підтримка 3 огляду на норми закону «Про державно-приватне партнерство» [2] обмежується низкою заходів стосовно приватного партнера. Ці заходи фінансуються в рамках укладених угод через такі форми забезпечення:

- надання гарантій, тобто відповідальність за взяті приватним партнером зобов'язання несе публічний партнер, формуючи гарантований державний борг;

- програмно-цільове бюджетування, тобто у рамках бюджетних програм відповідного бюджету здійснюється фінансування визначених заходів на безповоротній основі (наприклад, через субсидіювання або здійснення державних закупівель);

- використання державної та комунальної власності з метою фінансування будівництва, реконструкції, реставрації, капітального ремонту, технічного переоснащення тощо об'єктів суміжної інфраструктури (залізничних, автомобільних шляхів, ліній зв'язку, засобів тепло-, газо-, водо- та електропостачання, інженерних комунікацій тощо).

3 огляду на існуючу практику, потенційними інструментами інвестування інфраструктурних проєктів для публічного інвестора можуть бути такі:
- придбання акцій проєктної компанії публічним партнером із метою отримання частини прибутку від операційної діяльності, що посилює інституціональну структуру інфраструктурного проєкту. Такий механізм зазвичай реалізується за допомогою бюджетних інвестицій;

- бюджетні кредити, які надаються приватному партнеру під повне ліквідне забезпечення. На практиці такий інструмент є альтернативою субвенціям, але на відміну від останніх він відповідає принципам платності, строковості та зворотності;

- TIF-позики (Tax Increment Financing - TIF) або фінансування за рахунок боргу в очікуванні майбутніх податкових платежів, які за обсягом забезпечать повернення вкладених коштів [3].

Якщо перші два інструмента $є$ застосовуваними у тій або іншій мірі в український практиці, то TIF-проєкти не мають поширення в Україні. Слід звернути увагу, що TIF-проєкти $є$ інструментом органів місцевого самоврядування і використовуються для розвитку територій або окремих районів.

Для з'ясування переваг щодо використання такого інструменту досліджувався міжнародний досвід, 3 огляду на який визначено його способи використання:

- випуск TIF-облігацій. Виникаючі зобов'язання погашаються за рахунок майбутніх податкових платежів. Відмінною рисою таких облігацій $є$ відсутність рейтингу, що робить їх більш прибутковим і водночас більш ризиковим фінансовим інструментом [4, с. 54]. Існує практика, коли органи місцевого самоврядування здійснюють рефінансування, тобто викупають TIF-облігації без рейтингової оцінки з більш високим купоном і заміняють їх облігаціями інвестиційного напряму з більш низькою процентною ставкою, як тільки проєкт стабілізується і вийде за межі ризиків розвитку. На цьому етапі місцевий уряд уважає, що рівень ризику проєкту досяг прийнятного рівня і його доцільно «включити» у свою загальну базу зобов'язань;

- надання позики на створення інфраструктури, яка погашається за рахунок майнових платежів у зв'язку з використанням активу як продукту інфраструктурного проєкту [5, с. 4-6].

Практика реалізації TIF-проєктів досить поширена у США, Канаді, Великобританії та Індії. У США, наприклад, на основі TIF набули поширення інфраструктурні проєкти з підвищення енергоефективності діючих електростанцій, розвитку локальних територій та ін.

В Україні використання такого інструменту, як TIF-проєкти, неможливо на нинішньому етапі, оскільки існують обмеження адміністративного характеру. По-перше, йдеться про адміністративні бар'єри, які виникають у зв'язку з проблемами щодо розмежування повноважень між різними рівнями бюджетної системи. По-друге, виникає необхідність у створенні державних інвестиційних фондів, що потребує певного законодавчого забезпечення. По-третє, існує складність в обліку і розподілі податкових надходжень із причин відсутності роздільного обліку податків. 
Проте досвід використання TIF-проєктів можливо адаптувати до використання в Україні через формування державних інвестиційних фондів, джерелами фінансування яких можуть бути компенсаційні виплати, одержувані у вигляді платні за використання активу, створеного на засадах ППП через проєктне фінансування (наприклад, плата за проїзд через міст, плата за використання шляхів, плата за електроенергію або водопостачання тощо).

Якщо досліджувати джерела фінансування приватного партнера, то варто зауважити, що інструменти є акції та довгострокові позики.

Учасники фінансового ринку виходячи 3 існуючої практики фінансування інфраструктурних проєктів на засадах ППП становлять найбільшу питому вагу (60-80\%) через використання таких фінансових інструментів, як акції та довгострокові кредити. Безумовно, для цього національні фондові ринку мають бути достатньо розвинуті.

Порівняно з традиційними корпоративними облігаціями проєктні облігації у світовій практиці мають такі відмінності [6, с. 24]:

- цільове використання коштів інвесторів;

- прив'язка до експлуатації конкретних об'єктів;

- підвищена надійність у зв'язку зі складним механізмом розподілу ризиків;

- довгостроковий період обороту, який залежить від терміну будівництва (реконструкції) інфраструктурного об'єкта і періоду його експлуатації/окупності;
- забезпечення облігаційного випуску, у тому числі державними гарантіями, заставою майнових прав, страхуванням ризиків, банківськими гарантіями, поручительствами та іншими способами забезпечення.

Висновки. Підсумовуючи вищевикладене, можна дійти висновку, що використання фінансового механізму партнерства викликано об'єктивною необхідністю забезпечення економічного зростання за допомогою консолідації фінансових ресурсів бізнесу і держави 3 метою фінансування соціально та економічно значущих проєктів за мінімального рівня ризиків і з оптимальними витратами.

Проєкт - це форма ППП, яка має відміну від інших форм, оскільки існує в чітко обмежених часових рамках, як правило, охоплює кілька видів діяльності, а також несе значні ефекти (у тому числі зовнішні).

Під час реалізації ППП-проєкту шляхом застосування різного фінансового інструментарію у забезпеченні інфраструктури приватний партнер отримує можливість здійснювати господарську діяльність, пов'язану з експлуатацією суспільно значущих об'єктів, що дає йому можливість отримувати фінансові потоки від експлуатації цих об’ єктів і в такий спосіб формувати свій прибуток.

Досліджувана проблематика є достатньо широкою і потребує подальшого дослідження. Зокрема, до питань, які потребують поглиблення, можна віднести такі, як аналіз та контроль ефективності інвестицій, спрямованих на фінансування інфраструктурних проєктів на засадах ППП.

\section{Список літератури:}

1. Beckers Frank. Symbulos Infrastructure Consultancy External Adviser to McKinsey \& Company : New approach to infrastructure PPP, 2015. $56 \mathrm{p}$.

2. Про державно-приватне партнерство : Закон України від 01.07.2010 № 2404-VI. Biдомості Верховної Ради Украӥни. 2010. № 40. Ст. 524.

3. Richard F. Dye, David F. Merriman. Tax Increment Financing A Tool for Local Economic Development. Retrieved. URL: https://www.lincolninst.edu/sites/files/pubfiles/tax-increment-financing-lla060102.pdf (дата звернення: 28.03.2021).

4. Ларионова И.В., Лаврушин О.И. Формирование финансовой поддержки банками и финансовыми организациями инвестиционных проектов и мероприятий по энергосбережению и повышению энергоэффективности : монография / под ред. И.В. Ларионовой. Москва : КноРус, 2017. 119 с.

5. Eldrup A., Schütze P.A. Path to economic growth and development of the Danish welfare model. Copenhagen : DJØF Publishing. 2013. 116 p.

6. Манкулова Ж. Альтернативные источники финансирования инфраструктурных проектов. Корпоративный юрист. 2008. № 10. С. 24-26.

\section{References:}

1. Beckers Frank (2015) Symbulos Infrastructure Consultancy External Adviser to McKinsey \& Company: New approach to infrastructure PPP, 2015.

2. Pro derzhavno-pryvatne partnerstvo : Zakon Ukrainy vid 01.07.2010 №2404-VI [On public-private partnership: Law of Ukraine of 01.07.2010 42404-VI]. Verkhovna Rada Ukrainy. Vidomosti Verkhovnoi Rady Ukrainy, no. 40 , p. 524. (in Ukrainian).

3. 3Richard F. Dye, David F. Merriman. Tax Increment Financing. A Tool for Local Economic Development. Available at: https://www.lincolninst.edu/sites/files/pubfiles/tax-increment-financing-lla060102.pdf (accessed 28 April 2021).

4. Laryonova, Y.V., Lavrushyn, O.Y. (2017) Formirovanie finansovoj podderzhki bankami i finansovymi organizaciyami investicionnyh proektov i meropriyatij po energosberezheniyu i povysheniyu energo-effektivnosti [Formation of financial support by banks and financial organizations for investment projects and measures for energy saving and energy efficiency]. Moskow: KnoRus. (in Russia)

5. Eldrup A., Schütze P.A. (2013) Path to economic growth and development of the Danish welfare model. Copenhagen: DJØF Publishing.

6. Mankulova Zh. (2008) Alternativnye istochniki finansirovaniya infrastrukturnyh proektov [Alternative sources of financing for infrastructure projects]. Korporatyvnyi yuryst, vol.10, pp. 24-26. (in Russia) 